\title{
PERBEDAAN KEMAMPUAN PEMECAHAN MASALAH MATEMATIKA SISWA MENGGUNAKAN MODEL PEMBELAJARAN PROBLEM BASED LEARNING DAN MODEL PEMBELAJARAN DISCOVERY LEARNING PADA MATERI BANGUN RUANG DI KELAS V SDN 52 KENDARI
}

\author{
Riski Ramadhan ${ }^{1)}$, La Ode Kaimudin ${ }^{1)}$, La Ili ${ }^{1)}$ \\ ${ }^{1)}$ Jurusan Pendidikan Guru Sekolah Dasar \\ FKIP Universitas Halu Oleo \\ email: riskiramadhana1g116035@gmail.com, laodekaimudint30@gmail.com, \\ la.ili@uho.ac.id
}

\begin{abstract}
Abstrak: Penelitian ini bertujuanuntuk mengetahui perbedaan kemampuan pemecahan masalah matematika siswa dengan menggunakan model pembelajaran model Problem Based Learning dan model pembelajaran Discovery Learning pada materi bangun ruang di kelas V SDN 52 Kendari tahun pelajaran 2019/2020. Penelitian ini merupakan penelitian kuantitatif dengan jenis penelitian eksperimen, yang menggunakan desain penelitian nonequivalent control group desain. Populasi pada penelitian ini adalah seluruh siswa kelas V tahun ajaran 2019/2020 yang berjumlah 93 siswa. Sampel penelitian ini adalah kelas Vb yang berjumlah 28 siswa, sebagai kelas eksperimen I dan kelas Vc yang berjumlah 30 siswa, sebagai kelas eksperimen II. Teknik pengumpulan data dilakukan dengan teknik tes kemampuan pemecahan masalah matematika siswa yang diberikan dalam bentuk essay test dan teknik dokumentasi. Teknik analisis data menggunakan analisis deskriptif dan analisis inferensial. Berdasarkan analisis data dan pembahasan, diperoleh kesimpulan bahwa terdapat perbedaan kemampuan pemecahan masalah matematika siswa menggunakan model problem based learning dan model pembelajaran discovery learning pada materi bangun ruang kelas V SDN 52 Kendari, dengan nilai $t_{\text {hitung }}=2,342>t_{\text {tabel }}=2,021$ atau nilai sig. ( 2 tailed) 0,012 $<\alpha=0,05$.
\end{abstract}

Kata Kunci: Model Pembelajaran Problem Based Learning; Model Pembelajaran Discovery Learning; Kemampuan Pemecahan Masalah Matematika

\section{DIFFERENCES IN STUDENTS 'MATHEMATICS PROBLEM SOLVING ABILITY USING PROBLEM BASED LEARNING LEARNING MODEL AND DISCOVERY LEARNING LEARNING MODELS ON THE MATERIAL BUILD A ROOM IN CLASS V SDN 52 KENDARI}

\begin{abstract}
This study aims to determine differences in solving abilities Mathematical problems of students using model learning models Problem Based Learning and Discovery Learning learning models on the material build a room in class V SDN 52 Kendari in the academic year 2019/2020. This research is a quantitative research with quasi-experimental type of research, which is using a nonequivalent control group design research design. The population in this study were all fifth grade students of the school year 2019/2020 with 93 students. The sample of this study is the total population class $V$, that is class $V b$ with a total of 28 students, as experimental class I and Vc class of 30 students, as experimental class II. Technique Data collection is done by problem solving ability testing techniques Student mathematics is given in the form of essay tests and documentation techniques. Data analysis techniques using descriptive analysis and inferential analysis. Based on data analysis and discussion, it was concluded that there were differences in students' mathematical problem solving abilities using the problem based learning model and discovery learning learning model in class $V$ building materials SDN 52 Kendari, with $t_{\text {hitung }}=2.334>t_{\text {tabel }}=$ 2.021 or sig. (2 tailed) $0.012<\alpha=0.05$.
\end{abstract}

Keywords: Problem Based Learning Learning Model, Discovery Learning Learning Model, Mathematical Problem Solving Ability 


\section{Pendahuluan}

Matematika sebagai ilmu yang mendasari perkembangan teknologi modern yang mempunyai peranan penting dalam berbagai disiplin ilmu. Mulyana (2008) mengatakan pada awal pembelajaran matematika siswa seyogyanya dihadapkan pada masalah, selanjutnya siswa diberikan kesempatan secara mandiri untuk menyelesaikan masalah tersebut sehingga siswa dapat mengembangkan kemampuan aktualnya secara optimal. Oleh karena itu kemampuan siswa untuk belajar mandiri dan mampu berpikir kritis perlu terus dikembangkan. Tujuan umum pembelajaran matematika menurut National Council of Teachers of Matematics atau NCTM (2000) yaitu siswa harus mempelajari matematika melalui pemahaman dan aktif membangun pengetahuan baru dari pengalaman dan pengetahuan yang dimiliki sebelumnya. Untuk mewujudkan hal itu, dirumuskan lima standar pokok pembelajaran matematika, yaitu: pertama, belajar untuk berkomunikasi (mathematical communication); kedua, belajar untuk bernalar (mathematical reasoning); ketiga, belajar untuk memecahkan masalah (mathematical problem solving); keempat, belajar untuk mengaitkan pengertian ide (mathematical connections); dan kelima, pembentukan sikap positif terhadap matematika (positive attitudes toward mathematics) (Wiyanti \& Leonard, 2017, p. 612).

Dalam tujuan pembelajaran matematika diatas disebutkan bahwa salah satu tujuan pembelajaran matematika di sekolah adalah siswa mampu memecahkan masalah. Hal ini mendasari pentingnya pemecahan masalah dalam pembelajaran matematika. Masalah merupakan suatu soal yang harus dipecahkan oleh seseorang, tetapi cara/langkah untuk memecahkannya tidak segera ditemukan oleh orang itu. Orang yang menghadapi masalah berusaha menemukan cara menyelesaikannya sehingga diperoleh jawaban.Pemecahan masalah merupakan salah satu aspek yang penting dalam pembelajaran matematika. Menurut Sugiman dkk (2009:1) pembelajaran matematika disekolah seharusnya berfokus pada peningkatan kemampuan siswa dalam memecahkan masalah matematik yang meliputi aspek pengetahuan, konseptual/prosedural, strategi, komunikasi, dan akurasi (Sunendar, 2017, p. 87).

Hal ini berdasarkan hasil observasi dan wawancara dengan guru kelas V SDN 52 Kendari yang peneliti lakukan pada tanggal 28 Oktober 2019 bahwa siswa kelas V SDN 52 Kendari masih sulit memahami soal matematika berbasis soal cerita. Hal ini dapat terlihat dari latihan soal yang diberikan kepada siswa pada materi operasi hitung satuan waktu diperoleh data hanya 3 dari 58 siswa yang menjawab benar dengan langkah-langkah pemecahan masalah. Berdasarkan hasil observasi yang menyebabkan hal tersebut yaitu tingkat pemahaman terhadap suatu bacaan masih rendah, guru sering memberikan rumus tanpa memberi tahu cara atau konsep awal, kurangnya guru memberikan soal cerita, dan model pembelajaran yang dipilih guru kurang menarik sehingga tidak bemakna.

Menurut NCTM (2000:52) mengemukakan bahwa, Problem solving is an integral part of all mathematics learning, and so it should not be an isolated part of the mathematics program". Artinya, pemecahan masalah merupakan bagian integral dalam pembelajaran matematika, sehingga tidak boleh dipisahkan dari pembelajaran matematika Hal tersebut dapat dimengerti bahwasanya pemecahan masalah bukan hanya menjadi tujuan pembelajaran Matematika, tetapi juga alat untuk memahami Matematika itu sendiri (Riastini \& Mustika, 2017, p. 189)Selanjutnya, O'Daffer, dkk. (2008:41) mengungkapkan bahwa, "problem solving is a process by which an individual uses previously learned concepts, facts, and relationships, along with various reasoning skills and strategies, to answer a question or questions about a situation". Hal tersebut dapat diartikan bahwa pemecahan masalah adalah proses yang dilakukan seorang individu untuk menjawab pertanyaan tentang suatu situasi menggunakan konsep-konsep, fakta-fakta, dan hubungan- 
hubungan yang dipelajari sebelumnya, serta menggunakan berbagai keterampilan penalaran dan strategi (Riastini \& Mustika, 2017, p. 190).

Kemampuan memecahkan masalah menurut BSNP (2006) yakni meliputi kemampuan memahami masalah, merancang model matematika, menyelesaikan model, dan menafsirkan solusi yang diperoleh. Menurut Chotimah (2014) kemampuan pemecahan masalah matematika adalah kemampuan megidentifikasi unsur-unsur yang diketahui, ditanyakan, dan kecukupan unsur yang diperlukan, mampu membuat atau menyusun model matematika, dapat memilih dan mengembangkan strategi pemecahan, mampu menjelaskan dan memeriksa kebenaran jawaban yang diperoleh (Mawaddah \& Anisah, 2015, pp. 6667).

Secara garis besar indikator kemampuan pemecahan masalah menurut Polya 1985 dalam (Kaimuddin, 2013, p. 83)yaitu terdiri daribeberapa langkah yaitu, pemahaman masalah (Understanding the problem), membuat rencana pemecahan (Make solution plan), melaksanakan rencana perhitungan (Carry out the calculation plan) dan memeriksa kembali hasil perhitungan (Recheck the calculation results).

Pembelajaran yang diberikan kepada siswa sebelum dilakukan analisis kemampuan pemecahan masalah matematika siswa adalah pembelajaran yang menuntut siswa agar belajar lebih banyak. Suatu pembelajaran yang menjadikan siswa sebagai aktor utama dalam proses pembelajaran, bukan sebagai subjek yang hanya menerima pemberian dari guru. Salah satu model pembelajaran yang memenuhi karakter tersebut adalah model pembelajaran problem based learning dan model pembelajaran discovery learning.

Duch (2005) mengemukakan, bahwa PBL merupakan model pembelajaran yang menantang siswa untuk belajar bagaimana belajar, bekerja secara berkelompok, untuk mencari solusi dari permasalahan dunia nyata. Arends (2001) mendefinisikan PBL sebagai suatu model pembelajaran dimana siswa dihadapkan pada masalah autentik (nyata) sehingga diharapkan dapat menyusun pengetahuan sendiri, menumbuhkembangkan inkuiri dan keterampilan tingkat tinggi, memandirikan siswa dan meningkatkan kepercayaan dirinya (Lestari \& Yudhanegara, 2018, p. 42). Selain itu PBL adalah suatu model pembelajaran yang melibatkan siswa untuk memecahkan suatu masalah melalui tahaptahap metode ilmiah sehingga siswa dapat mempelajari pengetahuan yang berhubungan dengan masalah tersebut dan sekaligus memiliki keterampilan untuk memecahkan masalah (Hasibuan \& Sinaga, 2017, p. 20). Adapun langkah-langkah dari model pembelajaran problem based learning adalah orientasi siswa pada masalah, mengorganisasi siswa untuk belajar, membimbing pengalaman individu/ kelompok, mengembangkan dan menyajikan hasil karya, dan menganalisis dan mengevaluasi proses pemecahan masalah (Nurdin \& Adriantoni, 2016, pp. 266-267).

Sedangkan Model pembelajaran Discovery Learning menekankan kepada aktivitas siswa secara maksimal untuk mencari dan menemukan, artinya discovery learning menempatkan siswa sebagai subjek belajar. Dalam proses pembelajaran, siswa tidak hanya berperan sebagai penerima pelajaran melalui penjelasan guru secara verbal, tetapi mereka berperan untuk menemukan sendiri inti dari materi pelajaran itu sendiri (Hasibuan \& Sinaga, 2017, p. 21).

Belajar penemuan adalah proses belajar dimana guru harus menciptakan situasi belajar yang problematis, menstimulus siswa dengan pertanyaan-pertanyaan, mendorong siswa mencari jawaban sendiri, dan melakukan eksperimen (Mubarok \& Sulistyo, 2014, p. 217).Discovery learning merupakan suatu model pemecahan masalah yang akan bermanfaat bagi anak didik dalam menghadapi kehidupannya di kemudian hari (Rosarina, Sudin, \& Sujana, 2016, p. 374). Menurut Joolingen dalam (Putrayasa, Syahruddin, \& Margunayasa, 2014, p. 3) menjelaskan bahwa "discovery learning adalah suatu tipe 
pembelajaran dimana siswa membangun pengetahuan mereka sendiri dengan mengadakan suatu percobaan dan menemukan sebuah prinsip dari hasil percobaan tersebut".

Menurut Sinabela dalam (Yuliana, 2018, p. 22)langkah-langkah model pembelajaran discovery learning yaitu stimulation (pemberian rangsangan), problem statement(pernyataan/ identifikasi masalah), data collection (pengumpulan data), data processing (pengolahan data), verification (pembuktian) dan generalization (menarik kesimpulan/generalisasi).

Sedangkan Materi Bangun Ruang adalah materi yang sangat banyak digunakan dalam keadaan sehari-hari dan materi ini sangat mendukung untuk dilakukannya model pembelajaran Problem Based Learning dan Discovery Learning. Hal ini disebabkan kedua model pembelajaran menggunakan keadaan yang ada dalam kehidupan sehari-hari. Dengan menerapkan model pembelajaran Problem Based Leaning (PBL) dan Discovery Learning yang menggunakan keadaan nyata sebagai objek pembelajaran, pengeteahuan siswa akan semakin lekat didalam diri siswa tersebut.

Berdasarkan uraian di atas, masalah dalam penelitian ini adalah "Apakah terdapat Perbedaan kemampuan pemecahan masalah matematika siswa menggunakan model Problem Based Learning (PBL) dan model pembelajaran Discovery Learning pada materi bangun ruang di kelas V SDN 52 Kendari?"

\section{Metode Penelitian}

Penelitian ini dilakukan di SDN 52 Kendari, yang terletak di Jl.TunggalaNo.34, Kelurahan Anawai, Kecamatan Wua-Wua Kota Kendari Sulawesi Tenggara. Waktu pelaksanaan penelitian pada semester genap Tahun Ajaran 2019/2020

Jenis penelitian ini merupakan penelitian kuantitatif. Penelitian ini menggunakan desain penelitian eksperimen semu (quasi eksperiment) yaitu nonequivalent control group design.

Tabel 1. Rancangan Penelitian Nonequivalent Control Group Design

\begin{tabular}{lccc}
\hline \multicolumn{1}{c}{ Kelas } & Pretest & Treatmen & Posttest \\
\hline $\begin{array}{l}\text { PBL } \\
\text { (Eksperimen I) }\end{array}$ & $\mathrm{O}_{1}$ & $\mathrm{X}_{1}$ & $\mathrm{O}_{2}$ \\
\hline $\begin{array}{l}\text { Discovery Learning } \\
\text { (Eksperimen II) }\end{array}$ & $\mathrm{O}_{1}$ & $\mathrm{X}_{2}$ & $\mathrm{O}_{2}$ \\
\hline
\end{tabular}

Sumber: (Wulansari, 2017, p. 46)

Keterangan:

$\mathrm{O}_{1}:$ Pretest kemampuan pemecahan masalah

$\mathrm{X}_{1}$ : Perlakuan model Problem Based Learning (PBL)

$\mathrm{X}_{2}$ : Perlakuan model discovery learning

$\mathrm{O}_{2}$ : Postest kemampuan pemecahan masalah

Kegiatan awal untuk mengetahui kemampuan awal siswa diadakan tes awal (pretest). Kemudian siswa akan diberikan perlakuan dengan menggunakan model Problem Based Learning (PBL) untuk kelas eksperimen I dan model discovery learning untuk kelas eksperimen II. Pada akhir penelitian setelah diberikan perlakuan maka siswa akan diberikan tes akhir (posttest).

Populasi dalam penelitian ini adalah seluruh siswa kelas V SDN 52 Kendari tahun ajaran 2019/2020 yang berjumlah 93 siswa.Sampel dalam penelitian ini adalah kelas Vb yang berjumlah 28 siswa dan terdiri dari 18 siswa laki-laki \& 10 siswa perempuan sebagai kelas eksperimen I dan kelas Vc yang berjumlah 30 siswa dan terdiri dari 17 siswa lakilaki \& 13 siswa perempuan sebagai kelas eksperimen II di SDN 52 Kendari. 
Teknik pengumpulan data dalam penelitian ini yaitu teknik tes dan teknik dokumentasi. Teknik tes dilakukan dengan pemberian instrumen tes kemampuan pemecahan masalah matematika siswa yang terdiri dari pretest dan posttest dalam bentuk essay tes. Teknik dokumentasi dilakukan untuk merekam kegiatan penelitian.

Teknik analisis data yang digunakan dalam penelitian ini adalah analisis data statistic deskriptif dan analisis data statistic inferensial. Analisis deskriptif dilakukan dengan cara menjelaskan data pretest dan posttest yang disajikan dalam bentuk distribusi data yang sudah dikonversi menjadi nilai $N$-Gain (Gain Ternormalisasi) seperti mean, minimum, maximum, simpangan baku dan varians. Analisis inferensial dilakukan dengan cara uji normalitas menggunakan uji Kolmogrov Smirnov, uji homogenitas menggunakan uji levene test (One-way Anova), kemudian uji hipotesis menggunakan uji statistikindependent sample $t$-test (uji-t) dengan taraf signifikan $\mathrm{a}=5 \%$.

\section{Hasil Penelitian}

Hasil penelitian kuatitatif ini diperoleh dari analisis deskriptif dan analisis inferensial. Hasil analisisnya adalah sebagai berikut:

\section{Analisis Data Statistik Deskriptif}

Data kuantitatif yang dianalisis pada penelitian ini diperoleh dari hasil pretest dan posttest, sebelum adanya perlakuan dan setelah adanya perlakuan. Dalam penerapan model problem based learning untuk di kelas eksperimen I dan model pembelajaran discovery learning untuk kelas eksperimen II. Hal ini untuk melihat, perbedaan model pembelajaran problem based learning dan model pembelajaran discovery learning terhadap kemampuan pemecahan masalah matematika siswa. Data yang dianalisis adalah data $N$-Gain pada kemampuan pemecahan masalah matematika siswa kelas V SD Negeri 52 Kendari. Berikut ini tabel data klasifikasi $\mathrm{N}$-Gain kelas eksperimen I dan kelas eksperimen II.

Tabel 2. Data Klasifikasi N-Gain Kelas Eksperimen I dan Kelas Eksperimen II.

\begin{tabular}{cccccc}
\hline Normalized Gain & Klasifikasi & \multicolumn{2}{c}{ Jumlah Siswa } & \multicolumn{2}{c}{ Presentase (\%) } \\
\hline & & PBL & DL & PBL & DL \\
\hline$-1,00 \leq \mathrm{g}<0,00$ & Terjadi penurunan & - & - & - & - \\
\hline $\mathrm{g}=0,00$ & Tetap & - & - & - & - \\
\hline $0,00<\mathrm{g}<0,30$ & Rendah & 4 & 11 & 14,29 & 36,67 \\
\hline $0,30 \leq \mathrm{g}<0,70$ & Sedang & 23 & 19 & 82,14 & 63,33 \\
\hline $0,70 \leq \mathrm{g}<1,00$ & Tinggi & 1 & - & 3,57 & - \\
\hline Jumlah & & $\mathbf{2 8}$ & $\mathbf{3 0}$ & $\mathbf{1 0 0}$ & $\mathbf{1 0 0}$ \\
\hline
\end{tabular}

Berdasarkan tabel 2 di atas, diperoleh data nilai $\mathrm{N}$-Gain pada kelas eksperimen I pada klasifikasi yang "Tinggi" yakni pada interval $0,70 \leq \mathrm{g}<1,00$ dengan jumlah siswa 1 orang pada frekuensi 3,57\%. Klasifikasi "Sedang"yakni pada interval $0,30 \leq \mathrm{g}<0,70$ dengan jumlah siswa 23 orang pada frekuensi 82,14\%. Kemudian, klasifikasi yang rendah yakni pada interval $0,00<\mathrm{g}<0,30$ dengan jumlah siswa 4 orang pada frekuensi 14,29\%.

Sedangkan berdasarkan tabel di atas diperoleh data nilai $\mathrm{N}$-Gain pada kelas eksperimen II pada klasifikasi yang "Tinggi" yakni pada interval $0,70 \leq \mathrm{g}<1,00$ tidak tercapai. Klasifikasi "Sedang"yaitu pada interval $0,30 \leq \mathrm{g}<0,70$ dengan jumlah siswa 19 orang pada frekuensi $63,33 \%$. Kemudian, klasifikasi yang rendah yakni pada interval 0,00 $<\mathrm{g}<0,30$ dengan jumlah siswa 11 orang pada frekuensi 36,67\%. Berikut ini dapat disajikan dalam bentuk diagram frekuensi dan klasifikasi Normalized $N$-Gain kemampuan pemecahan masalah matematika siswa pada kelas eksperimen I. 


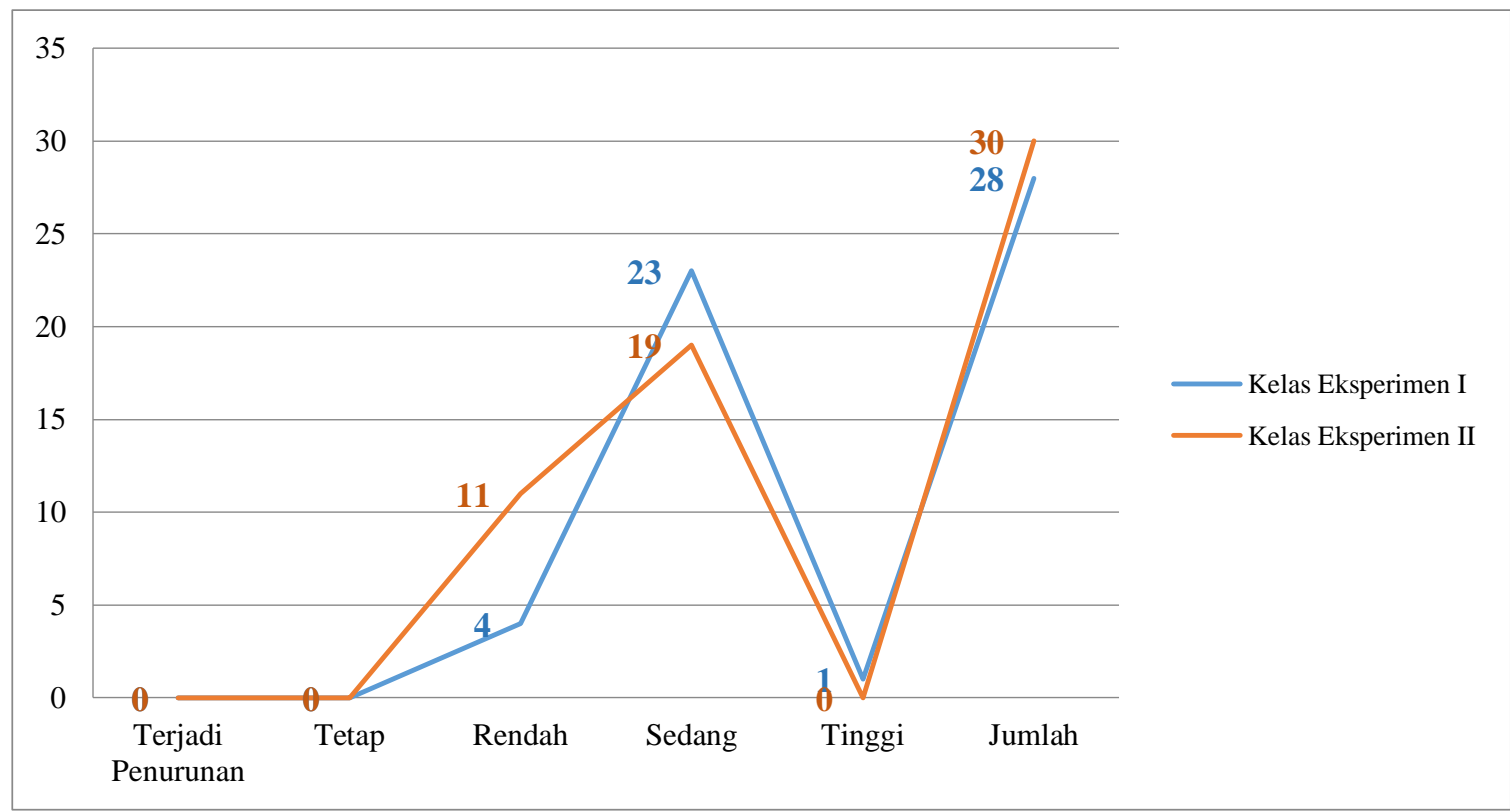

Gambar 1. Diagram Frekuensi dan Klasifikasi Normalized N-Gain Kemampuan pemecahan masalah matematika Siswa pada Kelas Eksperimen I dan Kelas Eksperimen II.

a) Hasil Data Analisis Statistik Deskriptif Peningkatan Kemampuan Pemecahan Masalah Matematika Kelas Eksperimen I dan Kelas Eksperimen II

Hasil penelitian tentang kemampuan pemecahan masalah matematika siswa, berdasarkan data klasifikasi $N$-Gain di kelas eksperimen I dan kelas Eksperimen II memiliki persamaan dan perbedaan. Kedua kelas tersebut memiliki persamaan pada nilai maksimum serta memiliki perbedaan pada nilai minimum, nilai rata-rata dan standar deviasi, serta varians sebagaimana yang disajikan pada tabel di bawah ini.

Tabel 3. Hasil UjiStatistik Deskriptif Peningkatan Kemampuan Pemecahan Masalah Matematika Siswa pada Kelas Eksperimen I dan Kelas Eksperimen II.

\begin{tabular}{lcc}
\hline \multirow{2}{*}{ Data } & \multicolumn{2}{c}{ Kelas } \\
\cline { 2 - 3 } & Eksperimen I & Eksperimen II \\
\hline $\mathrm{N}$ & 28 & 28 \\
\hline Nilai Rata-Rata & 0,4568 & 0,3652 \\
\hline Std. Deviasi & 0,14182 & 0,15491 \\
\hline Minimum & 0,23 & 0,11 \\
\hline Maximum & 0,74 & 0,61 \\
\hline Variance & 0,20 & 0,24 \\
\hline
\end{tabular}

Berdasarkan hasil analisis dekriptif kemampuan pemecahan masalah matematika siswa pada tabel di atas, didapatkan bahwa pada kelas eksperimen I dengan jumlah data 28 siswa diperoleh nilai rata-rata $N$-Gain 0,4568 dengan standar deviasinya sebesar 0,14182 dan varians sebesar 0,020. Sedangkan, pada kelas eksperimen II dengan jumlah siswa 30 siswa, diperoleh nilai rata-rata $N$-Gain sebesar 0,3652 dengan standar deviasinya sebesar 0,15491 dan varians sebesar 0,024 .

Untuk nilai $N$-Gain maksimum 0,74 dan nilai $N$-Gain minimum 0,23 mewakili 28 siswa pada kelas eksperimen I. Sedangkan nilai $N$-Gain maksimum 0,61 dan nilai nilai $N$-Gain minimum 0,11 mewakili 30 siswa pada kelas eksperimen II. 


\section{Analisis Data Statistik Inferensial}

Berikut ini tabel data statistik inferensial hasil data statistik uji normalitas, uji homogenitas, dan Uji t-test Independent.

Tabel 4. Data Statistik Inferensial Hasil Data Statistik Uji Normalitas, Uji Homogenitas, dan Uji $T$ Test Independent.

\begin{tabular}{lcc}
\hline \multicolumn{1}{c}{ Data } & \multicolumn{2}{c}{ Kelas } \\
\cline { 2 - 3 } & Eksperimen I & Eksperimen II \\
\hline Sig. Normalitas & 0,893 & 0,416 \\
\hline Sig. Homogenitas & \multicolumn{2}{c}{0,309} \\
\hline Uji t-test independent $_{\text {Sig. (2-tailed) }}$ & 0,23 \\
\hline $\mathrm{T}_{\text {hitung }}$ & 2,342 \\
\hline
\end{tabular}

Berdasarkan tabel 4 di atas, hasil uji normalitas untuk pengambilan keputusan apakah data normal atau tidak maka cukup membaca pada nilai signifikannya. (Asymp. Sig. (2-tailed). Jika signifikannya kurang dari 0,05 maka kesimpulannya data tidak berdistribusi normal, jika signifikansi lebih dari 0,05 maka dat berdistribusi normal.Pada tabel di atas, dapat diketahui bahwa nilai Asymp. Sig. (2-tailed) untuk kelas eksperimen I adalah $0,893>\alpha$ (dengan $\alpha=0,05)$, sehingga $\mathrm{H}_{0}$ diterima. Sedangkan pada kelas eksperimen II, terlihat bahwa nilai Asymp. Sig. (2-tailed) yakni $0,416>\alpha$ (dengan $\alpha=$ 0,05), sehingga $\mathrm{H}_{0}$ diterima. Jadi dapat disimpulkan bahwa $N$-Gain kemampuan pemecahan masalah matematika siswa pada kelas eksperimen I dan kelas eksperimen II berdistribusi normal.

Berdasarkan tabel di atas, hasil perhitungan uji homogenitas dengan taraf signifikan $\alpha=0,05$ dapat diketahui bahwa nilai signifikannya $>0,05(0,309>0,05)$, dari hasil analisis di atas dapat disimpulkan bahwa varian dua kelompok yakni kelas eksperimen I dan kelas eksperimen II adalah sama, maka hal ini telah memenuhi asumsi persyaratan dasar homogenitas.

Berdasarkan tabel 4.6 di atas, hasil uji-t diperoleh nilai $\mathrm{t}_{\text {hitung }}=2,342>\mathrm{t}_{\text {tabel }}=$ 2,021 (dapat dilihat pada lampiran), dan signifikans 0,05 nilai $\frac{\text { sig. }(2 \text {-tailed })}{2}=\frac{0,023}{2}=0,012$ $<0,05$ maka $\mathrm{H}_{0}$ ditolak. Sehingga terdapat berbedaan penggunaan model pembelajaran problem based learning dan model pembelajaran discovery learning terhadap kemampuan pemecahan masalah matematika siswa kelas V SDN 52 Kendari.

\section{Pembahasan}

\section{a. Kemampuan pemecahan masalah matematika siswa kelas Eksperimen I yang Menggunakan Model Pembelajaran Problem Based Learning}

Hasil analisis dekspkriptif pada kelas eksperimen I, diperoleh rata-rata N-Gain yaitu 0,4568 yang menunjukkan klasifikasi sedang karena berada pada interval $0,30 \leq \mathrm{g}<$ 0,70, standar deviasi (simpangan baku) sebesar 0,14182 yang menunjukkan bahwa besar penyimpangan data dari rata-rata kelas cukup. Sedangkan untuk varians datanya sebesar 0,20 yang menunjukkan bahwa keragaman kelas eksperimen I lebih kecil dibandingkan kelas eksperimen II. Hal ini menginterpretasi bahwa pembelajaran yang berlangsung merata pada semua siswa. Hal ini memberikan gambaran bahwa ada peningkatan kemampuan pemecahan masalah matematika siswa dengan penerapan model pembelajaran problem based learning (PBL).

Menurut Cunningham et al (Ikman, Hasnawati, \& Rezky, 2016, p. 362)bahwa that the problem-based learning as a learning strategy that simultaneously develop problem- 
solving strategies, disciplinary knowledge, and skills of putting students in activities to solve the problem by making the confrontation of the problem structure in the form of real problems in daily life -day. Through the model PBL students also learn to take responsibility for learning, not just receive information passively, but should actively seek the necessary information in accordance with existing capabilities, dapat di artikan bahwa pembelajaran berbasis masalah sebagai strategi pembelajaran yang secara simultan mengembangkan pemecahan masalah, pengetahuan disiplin, dan keterampilan menempatkan siswa dalam kegiatan untuk menyelesaikan masalah dengan membuat konfrontasi dari struktur masalah dalam bentuk masalah nyata dalam kehidupan seharihari. Melalui model PBL siswa juga belajar untuk mengambil tanggung jawab untuk belajar, bukan hanya menerima informasi secara pasif, tetapi harus secara aktif mencari informasi yang diperlukan sesuai dengan kemampuan yang ada.Selain itu juga dalam jurnal (Safrina \& Saminan, 2015, p. 312), Model PBL is an instructional model to create confrontation to students with problems as a stimulus in the studydapat diartikan bahwa model PBL adalah sebuah model pembelajaran untuk menciptakan konfrontasi dengan siswa dengan masalah sebagai sebuah stimulus dalam sebuah penelitian.

Hal tersebut terlihat jelas pada saat pembelajaran berlangsung. Dalam pembelajaran dengan modelproblem based learning, siswa mengerjakan permasalahanpermasalahan yang terdapat dalam LKS yang diberikan peneliti secara berkelompok kemudian berdiskusi untuk memecahkan masalah yang diberikan.Kegiatan kelompok secara tidak langsung memiliki keterampilan untuk menyelesaikan masalah secara mandiri. Hal itu sejalan dalam penelitian (Maryati, 2018, p. 65) bahwa problem based learning merupakan suatu model pembelajaran yang melibatkan siswa untuk memecahkan masalah melalui tahap-tahap metode ilmiah sehingga siswa dapat mempelajari pengetahuan yang berhubungan dengan masalah tersebut dan sekaligus memiliki keterampilan untuk memecahkan masalah. Dalam model pembelajaran PBL siswa dituntut untuk menyelesaikan masalah yang terdapat dalm LKS dan diberi kesempatan untuk saling bekerja sama, berbagi pengetahuan dengan anggota kelompoknya masing-masing. Kegiatan diskusi kelompok ini dapat memicu siswa yang memiliki kemampuan yang relatif tinggi dapat lebih memantapkan pemahaman dan kemampuan pemecahan masalahnya. Sedangkan siswa yang mempunyai kemampuan rendah dapat memperoleh pemahaman yang lebih baik yaitu penjelasan dari teman sebayanya.

\section{b. Kemampuan pemecahan masalah matematika siswa kelas Eksperimen II yang Menggunakan Model Pembelajaran Discovery Learning}

Berbeda dengan kelas eksperimen II ini yang menggunakan model pembelajaran discovery learning. Selama bebrapa pertemuan kemampuan pemecahan masalah matematika siswa boleh dikata kurang baik setelah diperoleh hasil tes akhir.

Berdasarkan hasil analisis deskriptif, diperoleh nilai rata-rata $\mathrm{N}$-Gain0,3652yang menunjukkan klasifikasi sedang karena berada pada interval $0,30 \leq \mathrm{g}<0,70$, standar deviasi (simpangan baku) sebesar 0,15491 yang menunjukkan bahwa besar penyimpangan data dari rata-rata kelas cukup. Sedangkan untuk variansnya sebesar 0,24 yang menunjukkan bahwa keragaman kelas eksperimen II lebih besar daripada kelas eksperimen I artinya data kelas eksperimen II lebih beragam daripada kelas eksperimen I.

Dalam pembelajaran menggunakan model pembelajaran discovery learning siswa diberikan LKS seperti biasa yang terkadang bukan merupakan masalah nyata, selain itu siswa kurang diberikan kesempatan untuk mengkonstruksi sendiri dalam menyelesaikan permasalahan matematikannya. Pada proses pemebelajaran di kelas ini, umumnya 
pembelajaran berpusat kepada guru sehingga guru lebih banyak berperan dari pada siswa itu sendiri. Hal senada yang diungkapkan dalam penelitian (Wiyanti \& Leonard , 2017) yang memandang bahwa pembelajaran matematika selama ini kurang melibatkan siswa secaraaktif, sebagaimana dikemukakannya bahwa "pembelajaran matematika selama ini disampaikan kepada siswa secara informatif, artinya siswa hanya memperoleh informasi dari guru saja sehingga derajat "kemelekatannya" juga dapat dikatakan rendah". Siswa kurang berusaha untuk menemukan sendiri pemecahan masalah yang diberikan oleh guru. Selain itu kelemahan dari model pembelajaran discovery learning menurut (Materi Pelatihan Guru Implementasi Kurikulum 2013) yaitu tidak efisien untuk mengajar jumlah siswa yang banyak, karena membutuhkan waktu yang lama untuk membantu mereka menemukan teori atau pemecahan masalah lainnya dan tidak menyediakan kesempatankesempatan untuk berpikir yang akan ditemukan oleh siswa karena telah dipilih terlebih dahulu oleh guru. Suasana yang monoton juga dapat mengakibatkan siswa mudah bosan. Akibatnya, hasil kemampuan pemecahan masalah matematika siswa di kelas eksperimen II lebih rendah dibanding kemampuan pemecahan masalah matematika siswa di kelas eksperimen I.

\section{c. Perbedaan Kemampuan Pemecahan Masalah Matematika Siswa Kelas Ekspserimen I dan II.}

Untuk mengetahui perbedaan pengaruh penggunaan modelproblem based learning dan model pembelajaran discovery learning terhadap kemampuan pemecahan masalah matematika siswa, maka dilakukan uji hipotesis untuk mendapatkan rata-rata nilai $\mathrm{N}$-Gain kemampuan penalaran matematis pada kedua kelas dengan menggunakan statistik independent sample test. Dengan terlebih dahulu melakukan uji prasyarat yaitu uji normalitas data kelas eksperimen dan kelas kontrol serta uji homogenitas varians kedua kelompok sampel.

Berdasarkan uji normalitas data dengan menggunakan analisis Nonparametric test-I sample $K$-S diperoleh untuk data kemampuan pemecahan masalah matematika siswa kelas eksperimen I dan kelas eksperimen II berdistribusi normal. Selanjutnya, berdasarkan uji homogenitas varins data kemampuan pemecahan masalah matematika kelas eksperimen I dan kelas eksperimen II menggunakan independent sample t-test diperoleh data kemampuan pemecahan masalah matematika siswa homogeny.

Kemudian dari hasil analisis inferensial diperoleh data $N$-Gainkelas eksperimen I dan kelas eksperimen II berdistribusi normal dan bersifat homogen, sehingga memenuhi syarat untuk melakukan pengujian hipotesis dengan menggunakan uji statistik uji-t independent sample t-test yang digunakan untuk menguji perbedaan rata-rata dua kelompok data yang independen. Dari pengujian hipotesis tersebut, diperoleh nilai $t_{\text {hitung }}=2,342$ dengan nilai sig. (2- tailed) sebesar 0,012. Karena $t_{\text {hitung }}=2,342>2,021$ dengan nilai signifikansi $0,012<\alpha=0,05$ yang berarti bahwa nilai $\mathrm{t}_{\text {hitung }}$ lebih besar dari nilai $\mathrm{t}_{\text {tabel }}$ dan nilai sig. (2- tailed) lebih kecil dari signifikansi $\alpha=0,05$ sehingga $\mathrm{H}_{0}$ ditolak yang berarti terdapat perbedaan pada penggunaan model problem based learning dan model pembelajaran discovery learning terhadap kemampuan pemecahan masalah matematika siswa. Hasil dari penelitian tersebut adalah bahwa model problem based learning lebih baik dari pada model discovery learning. Hal ini berarti terdapat pengaruh ataupun peningkatan dalam pembelajaran menggunakan model problem based learning (PBL) terhadap kemampuan pemecahan masalah matematika siswa.

Berdasarkan analisis hasil penelitian sebelumnya dan hasil uji hipotesis pada penelitian ini, dapat diketahui bahwa kemampuan pemecahan masalah matematika siswa 
pada kelas eksperimen I menggunakan model pembelajaran problem based learning lebih baik dari pada kelas eksperimen II yang diajarkan dengan menggunakan model pembelajaran discovery learning. Sehingga dapat disimpulkan bahwa ada perbedaan signifikan pada penggunaan model problem based learning dan model pembelajaran discovery learning terhadap kemampuan pemecahan masalah matematika siswa kelas V SD Negeri 52 Kendari.

Hambatan yang dihadapi peneliti dalam penelitianini adalah banyaknya siswayang masih memilikirasa ingin tahu yang rendah, kemudian terdapat beberapa siswa yang rebut saat proses pembelajaran dilaksanakan, dan juga siswa yang awalnya bingung ketika diberi masalah yang bagi mereka soal tersebut sangat sulit untuk mereka kerjakan.Untuk mengatasi hal tersebut peneliti memberi pendekatan intensif terhadap siswa yang memiliki rasa ingin tahu yang rendah dan membimbing siswa yang mulai merasa kebingungan, sehingga keadaan kelas tetap tertib dan kondusif.

\section{Simpulan}

Berdasarkan hasil penelitian dan pembahasan di atas, dapat disimpulkan bahwa terdapat perbedaan kemampuan pemecahan masalah matematika siswapada penggunaan model pembelajaran problem based learning dan model pembelajaran discovery learning. Hal ini didasarkan pada nilai signifikan uji independentsample t test diperoleh nilai $\mathrm{t}_{\text {hitung }}=$ 2,342 dengan nilai sig. (2-tailed) sebesar 0,012. Karena $t_{\text {hitung }}=2,342>t_{\text {tabel }}=2,021$ dengan nilai signifikansi $0,012<\alpha=0,05$ yang berarti nilai $t_{\text {hitung }}$ lebih besar dari nilai $t_{\text {tabel }}$ dan nilai sig. (2-tailed) lebih kecil dari signifikansi $\alpha=0,05$ yang berarti bahwa $\mathrm{H}_{0}$ ditolak, sehingga dapat disimpulkan bahwa terdapat perbedaan kemampuan pemecahan masalah matematika siswa menggunakan model problem based learning dan model pembelajaran discovery learning pada materi bangun ruang kelas V SDN 52 Kendari.

\section{Daftar Pustaka}

Ario, M. (2016). Analisis Kemampuan Penalaran matematis Siswa SMK Setelah mengikuti Pembelajaran Berbasis masalah. Jurnal Ilmiah Edu Research, 5(2), $125-134$.

Hasibuan, R., \& Sinaga, B. (2017). Perbedaan Kemampuan Pemecahan Masalah Matematika Menggunakan Model Pembelajaran Problem Based Learning Dan Discovery Learning Di Kelas Viii Smp Negeri 1 Percut Sei Tuan. Jurnal Inspiratif, 3(1), 17-28.

Ikman, Hasnawati, \& Rezky, M. F. (2016). Effect Of Problem Based Learning (Pbl) Models Of Critical. International Journal Of Education And Research, 4(7), 361374.

Kaimuddin. (2013). Konsep Dasar Matematika. Kendari: Fkip Unhalu.

Lestari, K. E., \& Yudhanegara, M. R. (2018). Penelitian Pendidikan Matematika. Bandung: Pt. Refika Aditama.

Maryati, I. (2018). Penerapan Model Pembelajaran Berbasis Masalah Pada Materi Pola Bilangan Di Kelas Vii Sekolah Menengah Pertama. Jurnal Mosharafa, 7(1), 6373. 
Mawaddah, S., \& Anisah, H. (2015). Kemampuan Pemecahan Masalah Matematis Siswa Pada Pembelajaran Matematika dengan Menggunakan Model Pembelajaran Generatif (Generative Learning) Di Smp. Jurnal Pendidikan Matematika, 3(2), 166-175.

Mubarok, C., \& Sulistyo, E. (2014). Penerapan Model Pembelajaran Discovery Learning Terhadap Hasil Belajar Siswa Kelas X Tav Pada Standar Kompetensi. Jurnal Pendidikan Teknik Elektro, 3(1), 215-221.

Nurdin, S., \& Adriantoni. (2016). Kurikulum Pembelajaran. Jakarta: Pt. Prajagravindo Persada.

Putrayasa, I. M., Syahruddin, H., \& Margunayasa, I. G. (2014). Pengaruh Model Pembelajaran Discovery Learning Dan Minat Belajar Terhadap Hasil Belajar Ipa Siswa. Jurnal Mimbar Pgsd Universitas Pendidikan Ganesha, 2(1), 1-11.

Riastini, P. N., \& Mustika, I. A. (2017). The Influence Of The Polya Model On The Mathematical Problem Solving Ability Of Fifth Grade Elementary School Students. International Journal Of Elementary Education, 1(3), 189-196.

Rosarina, G., Sudin, A., \& Sujana, A. (2016). Penerapan Model Discovery Learning Untuk Meningkatkan Hasil Belajar Siswa Pada Materi Perubahan Wujud Benda. Jurnal Pena Ilmiah, 1(1), 371-380.

Safrina, \& Saminan. (2015). The Effect Of Model Problem Based Learning (Pbl) (Case Study At Class VII MTsN Meureudu). Jurnal Ilmiah Peuradeun, 3(2), 311-321.

Sunendar, A. (2017). Pembelajaran Matematika Dengan Pemecahan Masalah. Jurnal Theorems (The Original Research Of Mathematics), 2(1), 86-93.

Wiyanti, \& Leonard . (2017). Pengaruh Model Problem Based Learning (Pbl). Prosiding Diskusi Panel Nasional Pendidikan Matematika, 3(1), 611-623.

Wulansari, D. N. (2017). Perbedaan Kemampuan Pemecahan Masalah Siswa Antara Model Pembelajaran Pbi Dan Cps. 1-334.

Yuliana, N. (2018). Penggunaan Model Pembelajaran Discovery Learning Dalam Peningkatan Hasil Belajar Siswa Di Sekolah Dasar. Jurnal Ilmiah Pendidikan Dan Pembelajaran, 21-25. 